\title{
Innovation in Sustainability Initiatives through Reverse Channels
}

\begin{abstract}
Purpose: This paper addresses to the research gap on the role played by a brand in creating value for business customers through the adoption of reverse channels by presenting a research agenda in the form of a conceptual framework. The research agenda discussed in this paper is based on the argument that a brand provides an assurance of the quality and functional capability of the products to new users of old products, delivers rational benefits to business customers, and strengthens the customer base of manufacturers.
\end{abstract}

Methodology/approach: A systematic literature review was conducted to develop propositions to develop deep insights into the role of a brand in creating value for business customers through the adoption of reverse channels.

Findings: Based on an extensive review of the literature, this study suggests that a brand can enhance customer equity, growth of the business customer and profits of the business customer by increasing in its efforts to influence the adoption of reverse-channels. Furthermore, the study proposes that an increase in the intention of a manufacturer to take on innovation in sustainability initiatives in its reverse logistics-based business process can increase the probability of the adoption of an approach towards reverse logistics. 
Research implications: This research extends the arguments made in innovation in sustainability initiatives theory by linking its three dimensions, i.e. economic, social and environmental, to reverse logistics and channel activities, as a function of a closed-loop supply chain.

Practical implications: Synthesis of various theories discussed in this paper provides a theoretical toolbox that can guide manufacturers of brands to create value by generating profits and enhancing the growth of industrial firms.

Originality/value/contribution: Using a systematic review of the literature, this study contributes to the area of research by developing a novel theoretical understanding of the role of a brand in creating value for business customers through the adoption of reverse channels.

KEYWORDS: Innovation, sustainability, reverse channels, value, growth, profit and brand equity 


\section{Introduction}

Can the promotion of a sustainable innovation through initiatives like reverse channel marketing, be influenced by a manufacturer offering branded products? Can such the manufacturer influence outcomes of the innovation in sustainability initiatives for different actors engaged in the process? Although the concept of recycling is well established, even today, it is based on used products as a function of operations management and has been defined by Carter and Ellarm (1998) as the reverse channel-based logistics. The practice dates back to the nineteenth Century and became a critical item of focus in the two world wars. The environmental side of it came to the fore during the early 1990s in Germany, because of government interventions. Reverse channels from a social viewpoint are an innovation in sustainability initiatives that use the channel-based business function as a closed loop supply chain (Guide, Jayaraman, and Linton 2003; Atasu, Toktay, and Van Wassenhove 2013; Lee and Lam 2013). There have been activities such as re-usable packaging, which can become a very cost-effective choice (Twede and Clark 2004; Besiou, Georgiadis, and Van Wassenhove 2012). In particular, the initiative of reverse channels includes returns management, recycling, waste disposal, re-manufacturing, and also marketing of the returned or remanufactured products. These activities are interrelated and dependent on business functions that are outside the scope of a traditional supply chain (Guide, Jayaraman, and Linton 2003; Lee and Lam 2013). They involve acquisition of used or less than up-to-date products from customers and supplying fully functional but refurbished products (Grewal, Iyer, and Levy 2004; Lee and Lam 2012). These activities create revenue and generate opportunities for firms managing repair and refurbishing activities. Industrial buyers or business customers, who are engaged in selling, consider such opportunities as additional value. This is because they generate extra revenue from the reuse of otherwise exhausted products and these projects allow the seller to adhere to the expectations of the society in relation to innovation 
in sustainability initiatives (Gupta, Czinkota, and Melewar 2012; VonRiesen and Herndon 2011).

Business customers evaluate the value contributed based on the rational benefits of associations (Srivastava, Shervani, and Fahey 1998). Competence to create such value for business customers rests on a manufacturer's ability to create demand, provide products that have special expertise in functionality and deliver products efficiently when there is a demand (Weerawardena and Mort 2006). While use of a brand helps in creating demand, the expertise required is for offering products with a high level of functionality and delivering them efficiently (Webster 2000). These external firms keep the manufacturer updated regarding changing trends and facilitate the smooth delivery of products to an appropriate consumer segment (Gupta, Grant, and Melewar 2008; VonRiesen and Herndon 2011).

The literature on segmentation explains as to how different segments of the market are concerned with different issues related to products and why they drive purchase behaviors in consumer markets (Ailawadi, Neslin, and Gednek 2001). Recent research of innovation in sustainability initiatives reflects the concerns of consumers about the ways brands communicate innovation in sustainability initiatives adopted by the manufacturer for influencing their preferences (Gupta, Czinkota, and Melewar 2012). Concurrently, products that satisfy societal requirements related to innovation in sustainability initiatives are sometimes very highly priced and do not fit the purchasing ability of a number of consumers (Velor 2007). Hence, consumers with low purchasing ability and high level of innovation in sustainability initiatives related concerns, have taken to buying refurbished products when offered at low prices (OECD Report 2010). A well-organized channel management of 
refurbished branded products improves the confidence of customers in the functional efficiency of pre-owned products (O’Rourke 2005). From a channel perspective, the goal becomes not just to deliver a product to the market, but to also to be able to retrieve it from the market for subsequent use, recycling, or disposal. Ideally, one uses the same channels both for the delivery and re-collection of products. To a growing degree, the ability to develop such two-way channel systems can become a key determinant for market acceptance and profitability (Czinkota and Ronkainen 2012). Also, as online purchases are on the increase, convenient returns of products become instrumental in convincing customers to purchase without physically examining the item (Jack, Powers, and Skinner 2009). There is a relationship between the rate of physical and marketing obsolescence, consumer attitudes to innovation and the economic feasibility of reverse logistics. The faster the technology progresses, the less feasible it is to recycle whole products and the more likely it is that products will only feasibly be recyclable for their components or even raw materials. This is unless consumers themselves drive trading of products which are feasibly fully recyclable.

Current academic knowledge is scant regarding the role played by a brand in creating value for business customers through the adoption of reverse channels. The authors present a research agenda based on the argument that a brand provides an assurance of the quality and functional capability of the products to new users of old products, delivers rational benefits to business customers, and strengthens the customer base of manufacturers (Gupta, Czinkota, and Melewar 2012; Van der Veen and van Ossenbruggen 2015). We will now present a research agenda in the form of a conceptual framework (Figure 1). The following section presents a review of the existing literature in this field of study, followed by recommendations for further research on this topic. 
Figure 1. Conceptual framework.

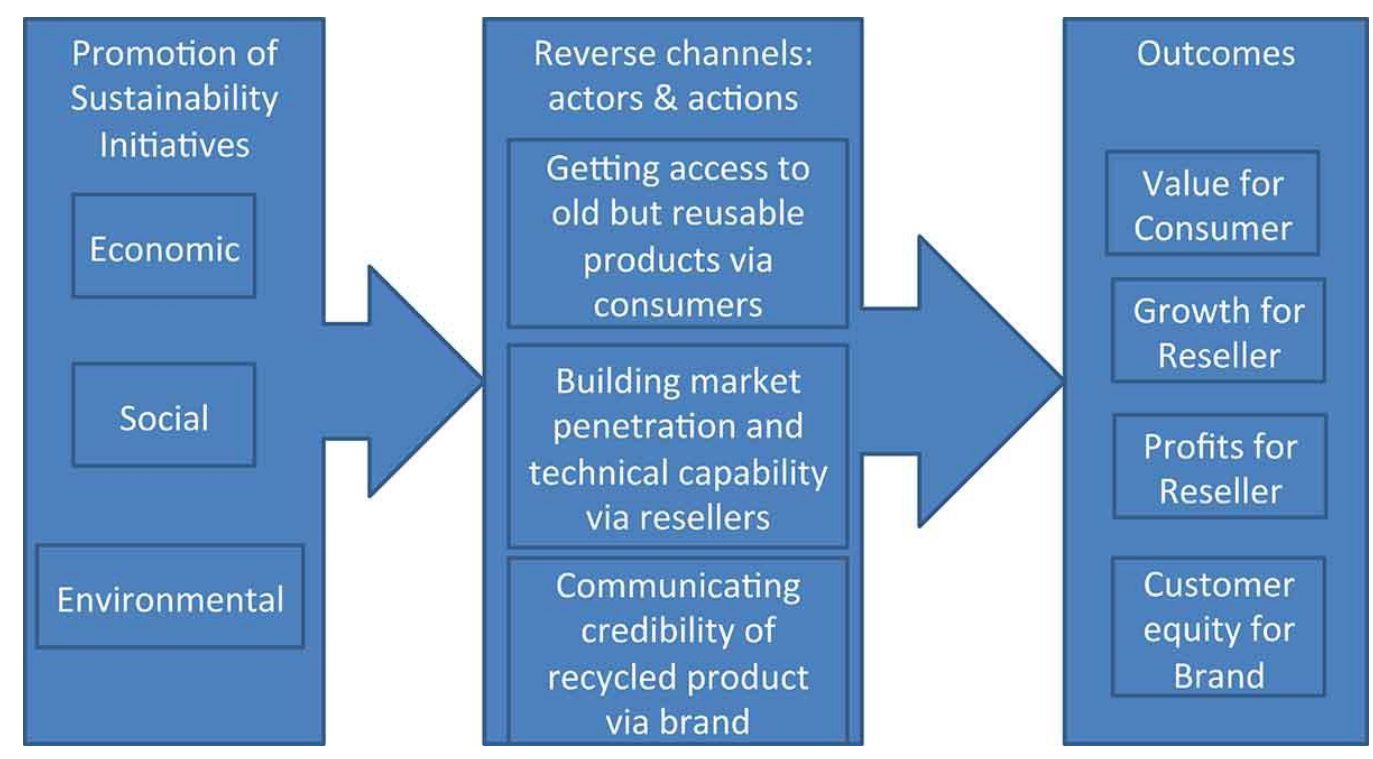

\section{Literature review and research propositions}

The existing literature defines reverse logistics as a business process that consists of activities related to the forward and backward flow of goods (Krikke, Bloemhof-Ruwaard, and Van 2003). Further exploration of reverse logistics reveals that the integration of marketing and sales opportunities with sustainability improves the efficiency of a business (Gunasekaran and Ngai 2004). The planning of reverse activities is a complex amalgamation of customer service, inventory control, information management, cost accounting, and disposal techniques including the management of hazardous materials (Czinkota and Ronkainen 2012). Even though sometimes onerous, international rules such as the ISO standard 14000 specifically target encouraging good international environmental practices, by evaluating companies both at the organization level (management systems, environmental performance, and environmental auditing) and at the product level (life cycle assessment, labelling and product standards) (Wu and Dunn 1995). Increasingly stakeholders also desire companies to develop 
practices that bring about fewer shipments, less handling, and more direct movement. The reverse logistics and reverse channels are based on closed-loop supply chains and this literature review discusses the ability of such integration to improve the effectiveness of business processes and advance the efficiency of demand management activities (Guide, Jayaraman, and Linton 2003).

Scholars like Atasu, Toktay, and Van Wassenhove (2013), investigated reverse channels from a perspective of operational issues faced by a manufacturer while adopting and implementing them. The authors have analyzed the issue of collection by the retailer, the manufacturer and a third party using collection cost function and found that the manufacturer's ability to shape the sales and collection quantity for optimal reverse channel choice, involving retailers, manufacturers, and other actors, is driven by the cost structure. As such, the extant studies fail to explain how a closed-loop supply chain based reverse channel requires manufacturers to utilize the competence of business partner firms (Persson and Virum 2001). When an innovation in sustainability initiatives like reverse channels-based closed-loop business practices extends the outcomes of an association beyond the creation of economic value, it can address social issues (Defee, Esper, and Mollenkopf 2009). An innovative supply chain that amalgamates reverse channels-based logistics improves customer equity for the manufacturing firm (Pagell and Wu 2009; Seuring et al. 2008) and drives growth and profitability for its partner firms (Pagell and Wu 2009; Seuring et al. 2008). The risk of failure of a supply chain that closes the loop of the life cycle of a product, through reverse logistics, needs to be understood. It can be reduced if the contribution to be made and received by each partner, in addition to their individual responsibility towards the performance and management of different functions, is known (Li et al. 2005). Together, if their roles are identified and integrated at the design stage of the supply chain - the firms can 
successfully ensure the efficient delivery of products up to the natural end of their life cycle (Li et al. 2005).

Management of reverse operations for a product through all stages of its life cycle requires collaboration between manufacturers and firms that can provide access to a market segment, ready to use pre-owned products (Gupta, Czinkota, and Melewar 2012). A study conducted by Besiou, Georgiadis, and Van Wassenhove (2012) reviewed waste management systems to understand the link between collection capacity shortage and the low living standards of consumers in developed countries, and presented a model that can be used to test the impact of scavenging end-of-use products using the operations of a formal recovery system. It enabled scholars to explore the influence of three different regulatory measures of innovation on sustainability initiatives and to conclude that incorporating scavengers to collect end-ofuse products into the formal system is beneficial. Although these studies have considered sustainability from different perspectives of reverse channels, they have not been able to clearly link them well with recycling and re-use of pre-owned products.

Manufacturers engage business customers for smooth management of the reverse flow of products from consumer markets, i.e. products that are returned by the consumer either due to their failure to function or due to the consumer's need to either change or upgrade them (Baum 2001). Consumers rely on the recommendations of sellers for the purchase of preowned products (OECD Report 2001; Guide, Jayaraman, and Linton 2003; Van der Veen and van Ossenbruggen 2015). Opportunities for reselling old products improve the assessment of economic value by business customers and the innovation in sustainability initiatives (Amit and Zott 2001). Retailers selling recycled products also act as quasi-representatives of the 
manufacturer and provide a "window" to those consumers who are seeking the repair of a faulty product or the purchase of a reliable pre-owned product (Vurro, Russo, and Perrini 2009). Retailers trained by the manufacturer function as important actors in the reverse logistics of a product, i.e. they bridge the gap between consumers and manufacturers by having the capability to repair and make the product ready for a new customer segment (Guide, Jayaraman, and Linton 2003; Gunasekaran and Ngai 2004).

In the case of wide geographic dispersion, manufacturers train and outsource the repair and refurbishing activity to retailers; such recycling initiatives improve the technical abilities of the retailer to add value to the manufacturer's business (Barratt and Rosdahl 2002). Recycling when managed as a support activity by a retailer or a business partner firm, enables the manufacturing firm to focus on its core business, without investing in the creation and management of resources or the infrastructure required for making their business sustainable through a closed loop supply chain (Gunasekaran and Ngai 2004). Although the strategy literature discusses the outsourcing of support activities and management of core activities by the firm for superior performance, it does not reflect on the capability of recycling when innovatively managed reverse logistics use an outsourcing model. Therefore, embedding these arguments into the resource-based view of Wernerfelt (1995) encourages us to propose:

Proposition 1: An increase in the intention of a manufacturer to take on innovation in sustainability initiatives in its reverse logistics-based business process can increase the probability of the adoption of an approach towards reverse logistics.

Brands provide an assurance of product quality with established demand (Webster 2000). The association of a brand with an external firm enhances a brand's ability to manage its 
customers efficiently (Boyson et al. 1999). Brand-based associations between a manufacturer and external firms strengthen with an increase in the value creation based on mutual capabilities and opportunities (Srivastava, Fahey, and Christensen 2001). External firms as partners in business collaborate to improve the efficiency of the brand's supply chain. A collaborative relationship between a brand and its business partners can result in the efficient management of both products and its consumers (Gunasekaran and Ngai 2004). Such collaborations aid the development of trust, in addition to the growth of the brand and the profitability of the partner firms (Shocker, Srivastava, and Ruekert 1994). A relationship of trust between partners in business cultivates value by enabling brand managers to assess the future requirements of the consumers through an integration of logistics and channel management with the sales and marketing function of the brand (Webster 2000). Such an integration depends on the design and implementation of a supply chain that originates with the manufacturer and ends with the consumers (Boyson et al. 1999).

Alvarado and Kotzab (2001) suggest that the integration of these two different domains has the capability of orchestrating activities between two different firms working together, towards the creation of mutual superior value. The integration of activities between two firms is a multifaceted phenomenon and has the ability to change the way the consumer is served. The nature of a supply chain that integrates marketing channels, sales, repair, and re-sales can lead to the creation of a closed loop supply chain that contributes value to both the brand and its business partners (Guide, Jayaraman, and Linton 2003). We view the channel as consisting of two subsystems, namely the channel management activities and the physical distribution activities (Papavassiliou et al. 2006). A mismatch between the logistics related services offered by business partners and the services required by brands for new, and pre-owned products can lead to high levels of dissatisfaction at both ends of the supply chain, and the 
possible failure of the relationship between a brand and its local business customers (Power, Sharafali, and Bhakoo 2007).

\section{Brand driven reverse channels}

The complexity and competitiveness of industrial markets require manufacturers to look for innovative business models that allow them to demonstrate their ability to create demand by addressing issues beyond profits and growth (Amit and Zott 2001; Woodruff 1997). Traditionally, manufacturers have been interested in adopting brand based or service-based business models that allow them to connect with the emotive needs and concerns of consumers (Gupta, Czinkota, and Melewar 2012). Recently, a pragmatic shift has been identified in the concerns of consumers, based on their awareness of the innovation in sustainability initiatives issues faced by mankind. Researchers primarily attribute industries and businesses as responsible for these innovations in sustainability initiatives related issues. Societally, it has become vital that manufacturers integrate innovation in sustainability initiatives with their products and business activities.

Yet, the marketing of innovation in sustainability initiatives-oriented products through reverse activities appears to be more complicated than in the case of new products (TibbenLembke and Rogers 2002). Tibben-Lembke and Rogers (2002) studied the reverse life cycle of branded products and reflected on their ability to maximize returns while maintaining brand integrity. Although previous research discusses as to how re-furbished pre-owned products when offered through reverse logistics encourage industrial customers to assess the value the brand contributes to their business in various formats, it fails to explain as to how 
the brand can influence the innovative adoption of sustainability initiatives. Therefore, we anticipate that:

Proposition 2: The presence of a brand can influence the efficiency of adoption of the reverse channels for promotion of innovation in sustainability initiatives taken up by a manufacturer.

\section{Value for industrial customers}

Value for customers in the business context has been discussed widely in the academic literature (Anderson, Thomson, and Wynstra 2000). Payne, Holt, and Frow (2001). Value management framework integrates factors such as determination, creation, delivery, and assessment in the generation of customer equity. The significance of value-based marketing has also been explained by Doyle (2001) as an important aspect of the business processes to be considered by firms seeking to create value for their customers. Lapierre (2000) studied value in the industrial context and empirically validated profit as an important determinant of value, as assessed by business customers, while Wong and Dean (2009), placed emphasis on both profits and growth for driving the assessments and loyalty of customers. This work integrates three different facets of value discussed by previous researchers as determinants of value for business customer in the context of the reverse management of a brand: customer equity, growth, and profit. In the following sections, these facets are individually explained and propositions for future research are made:

\section{Customer equity}

In a 2005 study of reverse logistics for innovation in sustainability initiatives in the institutional context, Richey et al. (2005) considered the reverse flow of goods through 
marketing channels. They assert that excellence in reverse logistics is a strategic variable that allows companies to build customer equity based on the high cost attached to switching between different customers when they look for an alternative provider. Gupta, Czinkota, and Melewar (2012) explored the innovation in sustainability initiatives related understanding of customers about reverse logistics and its ability to change the preferences of customers in a competitive market. It has been noted in the marketing literature (Keller 1993) that building customer equity through customer preferences based on their satisfaction and loyalty, leads to an increase in the cash flow of the company and improves its value as assessed by its stakeholders. Although the capability of environmental change drivers to increase customer satisfaction is recognized in the academic literature (Blocker and Flint 2007), its link with the value business customers look for from the reverse perspective and how it increases customer equity has not been explored. Hence, we argue that:

Proposition 3: An increase in efforts related to the management of reverse channels by a brand would enhance its customer equity by improving the business customers' assessment of the value offered by a brand.

\section{Growth}

The prime objective of small and medium-sized firms working as a part of the marketing channel of a manufacturer is the desire to grow their businesses using the value offered by the manufacturer (Webster 2000). When brands use such firms as their business customers they create opportunities of growth for the agent firms by increasing their customer base and the overall performance of their business (Gupta, Czinkota, and Melewar 2012). The differential effect of brand knowledge, built on the basis of favorable and unique brand associations has been explained in the marketing literature through the customer-based brand equity model by 
Keller (1993). Gupta, Czinkota, and Melewar (2012) explained as to how innovation in sustainability initiatives adopted by a brand influences the brand preferences of business consumers. Webster (2000) studied the three-way relationship between the brand, its consumers and business customers, with an aim to understand as to how value was delivered by brands in a market. Studies like Dick and Basu (1994), and Cherian and Jacob (2012) along with research conducted by Amit and Zott (2001) have used theories like the Theory of Reasoned Action to explain the influence of business performance on the assessment of value offered as business growth acknowledged by business customer firms. These studies have, however, failed to explain how the adoption of reverse channels in business practice can influence the growth of business customer firms. Hence, we explain our proposal as:

Proposition 4: An increase in efforts related to management of reverse channels by a brand will enhance the growth of the business customer firm.

\section{Profit}

Value-conscious customers increase the competition between marketing channels and encourage brand managers to focus not only on hedonic benefits but also on the economic benefits that a brand provides to customers. The need for companies to create a competitive advantage that addresses the value customers desire was addressed by Woodruff (1997), who proposed the use of outward orientation for the creation and implementation of customer value creation strategies. Profit also needs to be seen within the context of competition, risk and private property (Czinkota and Ronkainen 2012). Ailawadi, Neslin, and Gednek (2001) studied the effect of the psychographic and demographic characteristics of customers on the purchasing decisions they make. The psychographic characteristics were based on three dimensions - economic, hedonic and costs. The economic dimension was evaluated using 
savings made and product quality, whereas, the costs dimension was based on factors related to switching, searching, thinking and inventory. The hedonic dimension was assessed by Ailawadi, Neslin, and Gednek (2001) using variables related to the demographic features of respondents such as age, sex, education level, employment status, and annual household income. A combination of the two dimensions, i.e. psychographic and demographic, if grounded in profit-making aspect of reverse logistics, reveal the characteristics of customers who look for innovation in sustainability initiatives through refurbished pre-owned products offered by a brand that certifies the quality offered to them at a price that is affordable. A review of these arguments from the perspective of agency theory based on research conducted by $\mathrm{Zu}$ and Kaynak (2012) explains the contributions made by brands to the profits of business customer firms. But, they have failed to explain the argument from the perspective of reverse channel management practices. Therefore, we propose that:

Proposition 5: An increase in efforts related to management of reverse channels by a brand will enhance the profits of the business customer firm.

Webster (2000) suggests that the brand becomes valuable to both the consumer and the business customer when its marketing strategy is based on the careful coordination of its marketing and sales activities with the delivery of products. Simpson, Siguaw, and Baker (2001) proposes a model of value creation from the perspective of business partners which highlights the role of market orientation in creating relational benefits for partner firms in addition to driving the product quality and price of the product with its physical distribution through logistics, channels, and service support. According to Simpson, Siguaw, and Baker (2001), these factors cumulatively have the ability to improve the financial performance of the business partner while decreasing the overall cost of the product, the cost of creation of 
sales opportunities and the cost of selling. As proposed by Simpson, Siguaw, and Baker (2001), these factors improve the value of the brand as perceived by its business customers, increase their satisfaction with the relationship and improve their cooperation and commitment.

\section{Scope for innovation in sustainability}

A consumer population whose purchasing ability is highly diverse is an important feature of a large market (Prahlad and Hammond 2002). While one set of consumers in such markets seeks expensive luxury goods, a large segment in this market survives on very low income (Anderson and Markides 2007). At the same time, a large section of the lower middle class in these markets emerges as a consumer segment that seeks lifestyle-improving products (Kharas 2010). The distribution of income between different consumer segments requires businesses to adopt innovative business models and offer products, priced to satisfy the individual needs and aspirations of the consumers in each segment (Viswanathan et al. 2009). Such diverse consumer segments within a market, make it very attractive to the various brands seeking growth by the acquisition of a larger share of the consumer market (Kharas 2010). To capitalize on the market potential and exploit the resources available in that country, it becomes important that brand managers transform their business models into strategies that can allow them to satisfy consumers belonging to different segments (Gupta, Grant, and Melewar 2008).

In a market, that is geographically very large, business partners as resellers or retailers of a brand, provide access to remotely located consumer markets (Gupta, Grant, and Melewar 2008). If the business opportunities are high, the availability of a product at a price that is 
based on the purchasing ability of the consumers can improve the performance of the brand. Using resources available through business partner firms and create mutually beneficial value, a competitive market enables a brand to target consumers with different purchasing abilities (Guide, Jayaraman, and Linton 2003). It is likely that the value co-creation in the case of reverse logistics is limited for various reasons such as lack of strategic alignment, differences in priorities of the brand and customer firms, and varying interests of different stakeholders.

Markets with a large population also offer a large set of skilled labor, making it an attractive destination for businesses and their reverse channels (Gupta, Grant, and Melewar 2008). Based on a forward and reverse business model, brands that operate through business partners in competitive markets have the opportunity to implement a reverse supply chain (Guide, Jayaraman, and Linton 2003; Jayaraman and Luo 2007). A supply chain that supports innovation in sustainability initiatives through reverse logistics contributes to the growth and profitability of the business partner (Gupta, Czinkota, and Melewar 2012). Business customers, in turn, can facilitate the utilization of local resources such as the skilled manpower required to repair and refurbish products as per the quality guidelines provided by the brand and making them available to another set of consumers (Stark 2015).

\section{Research implications}

Apart from research opportunities, the topic of this research provides a number of implications for business-to-business theory and practice. The contemporary challenges faced by businesses require them to be actively engaged in adoptive sustainability promoting practices and initiatives that promote recycling and address issues related to waste 
management and climate change. Stakeholders today feel that it is important for brands and business managers to be conscious of these issues and consider these when they make strategic decisions about their operations and management approach. Today, companies that are internationally serving or remotely managing their business through a network of business customers can engage these customers as partners in a delivery chain for ensuring that their products are recycled and reused by a set of customers, before they are ultimately disposed of. The propositions made, represent the initial efforts to understand the role of a reverse channel in pushing a sustainability agenda through business customer firms. These initiatives that aim to ensure value creation for the business customers of a brand provide opportunities for both theoretical and empirical research on the topic. Before an empirical research process is initiated, we recommend that all potential cues in the existing literature regarding the topic be used to form a taxonomy that will aid the process of theory development.

\section{Innovation in sustainability initiatives as a precursor for promotion of reverse channels}

This research extends the arguments made in innovation in sustainability initiatives theory by linking its three dimensions, i.e. economic, social and environmental, to reverse logistics and channel activities, as a function of a closed-loop supply chain. The arguments presented can enable researchers to make detailed assumptions about the causality that exists between the different variables that operate between the innovation in sustainability initiatives undertaken by a manufacturer through a closed loop supply chain with an aim to create value for customers. Value thus created becomes an outcome of reverse logistics that has the ability to generate profits as an economic benefit and customer equity as a social benefit.

\section{Brand-driven reverse channels for a closed loop supply chain}


Based on the proposal of Marquardt, Golicic, and Davis (2011), the conceptual framework refers to reverse logistics being managed by a company that offers its products using a brand name. It is important to relate these arguments to the segmentation and positioning aspects of a brand based on the understanding that the reverse logistics adopted by a brand not only position the brand above its competitors, but also help fulfill innovation in sustainability initiatives requirements and their benefits as perceived by individuals through the provision of reliable and good quality products by the brand to a segment of customers that lacks high purchasing power. These initiatives simultaneously create value for business customers in the form of increased profits and customer equity.

\section{Value for business customers}

The concept underlying the propositions made is that the used products returned by consumers to other business customers of the brand will provide profit-making opportunities to businesses and manufacturers of brands. In order to address such opportunities, brands will be required to train their business customers, on the skills required to make the pre-owned product saleable to another set of customers. Hence, the management of the reverse flow of products from consumer to business customers and the further extension of the supply chain by readying the pre-owned products for future use will involve the manufacturing firm owning the brand. The ability of business customers that are knowledgeable and skilled to repair and refurbish branded products can lead to an increase in their customer equity with respect to customer segments that have varied purchasing power and profit earning capability. As the Volkswagen pollution measurement fracas in the United States has shown, the truthfulness and corrective intervention of firms can be another critical component for value creation (Czinkota and Enke 2014). The transactions of business customer firms with 
different segments of customers result not only in a larger customer base but also in improved earnings and business growth.

\section{Future research}

To summarise, the guidelines that we can provide for future research on this topic are related to innovation in sustainability initiatives that encourage the adoption of reverse logistics and use of a brand that can influence the efficiency of reverse logistics. We further explain as to how the adoption of reverse logistics can create value for industrial customers by improving the customer base and increasing the customer equity of the industrial firm. Our exploration reflects on the sale of both new and old goods through industrial firms (like goods received in part-exchange for new products) will increase profits and create value for business customers by improving their profile through the transfer of skills and knowledge about state-of-the-art products, through which industrial firms are likely to experience higher growth.

\section{Limitations}

This research has certain limitations that should be addressed by future research on the topic. It uses current theoretical understanding to propose relationships and make propositions for future research. The propositions made should be empirically validated for the purpose of generalization to different industry segments and business settings. A framework could be developed that incorporates the variables that are incidental to such a setting and that influence the efficiency of the propositions, e.g. for marketing initiatives adopted by competitors for both the consumer markets and business-to-business markets. Applicability of findings for both emerging economies and post-industrial societies requires additional 
research which uses data and enable managers operating in different markets to compare and contrast conditions, perceptions, and outcomes of such actions.

\section{Conclusion}

Determining value for business customers is a complex challenge for manufacturers owning brands. This study contributes to the ongoing debate regarding the integration of the marketing function with operations management for creating value that satisfies the requirements of society from a broader view than the individualistic personal view of customers. The role played by brands in creating value for small firms which facilitate the supply of products in a country wherein customers have a diverse range of purchasing abilities is explored based on existing knowledge. The use of reverse logistics as an initiative of a brand to promote innovation in sustainability initiatives as a part of its closed loop supply chain highlights the need for scholarly attention to this area of research. Synthesis of various theories provides a theoretical toolbox that can guide manufacturers of brands to create value by generating profits and enhancing the growth of industrial firms. 


\section{References}

Ailawadi, K. L., S. A. Neslin, and K. Gednek. 2001. Pursuing the value-conscious consumer: Store brands versus national brand promotions. Journal of Marketing 65 (1):71-89.

Alvarado, U. Y., and H. Kotzab. 2001. Supply chain management: The integration of logistics in marketing. Industrial Marketing Management 30 (2):183-98.

Amit, R., and C. Zott. 2001. Value creation in e-business. Strategic Management Journal $22(6 / 7): 493-520$.

Anderson, J., and C. Markides. 2007. Strategic innovation in sustainability initiatives at the base of the pyramid. MIT Sloan Management Review 49 (1):83-88.

Anderson, J. C., J. B. L. Thomson, and F. Wynstra. 2000. Combining value and price to make purchase decisions in business markets. International Journal of Research in Marketing 17 (4):307-29.

Atasu, A., L. B. Toktay, and L. N. Van Wassenhove. 2013. How collection cost structure drives a manufacturer's reverse channel choice. Production and Operations Management 22 (5):1089-102.

Barratt, M., and K. Rosdahl. 2002. Exploring business-to-business market sites. European Journal of Purchase and Supply Management 8 (2):111-1-122.

Baum, C. 2001. Trade sanctions and the rule of law: Lessons from China. Stanford Journal of East Asian Affairs 1 (Spring):46-74.

Besiou, M., P. Georgiadis, and L. N. Van Wassenhove. 2012. Official recycling and scavengers: Symbiotic or conflicting? European Journal of Operational Research 218 (2):563-76.

Blocker, C. P., and D. J. Flint. 2007. Exploring the dynamics of customer value in crosscultural business relationships. Journal of Business and Industrial Marketing 22 (4):249-59.

Boyson, S., T. Corsi, M. Dresner, and E. Rabinovich. 1999. Managing effective third party logistics relationships: What does it take? Journal of Business Logistics 20 (1):73-100.

Carter, C.R., and L.M. Ellram. 1998. Reverse logistics: a review of the literature and framework for future investigation. Journal Of Business Logistics, 19 (1):85-102.

Cherian, J., and J. Jacob. 2012. Green marketing: A study of consumers' attitude towards environment friendly products. Asían Social Science 8 (12):117.

Czinkota, M. R., and I. Ronkainen. 2012. International marketing. 10th ed. Cincinnati: CENGAGE.

Czinkota, M. R., and M. Enke. 2014. An international perspective on commodity marketing: Commodity marketing. Enke,Geigenmueller and Leischnig eds. 3rd ed., 405-19. Wiesbaden: SpringerGabler.

Defee, C. C., T. Esper, and D. Mollenkopf. 2009. Leveraging closed-loop orientation and leadership for environmental innovation in sustainability initiatives. Supply Chain Management: An International Journal 14 (2):87-98.

Dick, A. S., and K. Basu. 1994. Customer loyalty: Toward an integrated conceptual framework. Journal of the Academy of Marketing Science 22 (2):99-113.

Doyle, P. 2001. Value-based marketing. Journal of Strategic Marketing 8 (4):299-311.

Grewal, D., G. R. Iyer, and M. Levy. 2004. Internet retailing: Enabler, limiter and consequences. Journal of Business Research 57 (7):703-13.

Guide, V. D. R., Jr., V. Jayaraman, and J. D. Linton. 2003. Building contingency planning for closed-loop supply chains with product recovery. Journal of Operations Management 21 (3):259-79.

Gunasekaran, A., and E. W. T. Ngai. 2004. Information systems in supply chain integration and management. European Journal of Operational Research 159 (2):269-95. 
Gupta, S., M. Czinkota, and T. C. Melewar. 2012. Embedding knowledge and value of a brand into innovation in sustainability initiatives for differentiation. Journal of World Business 48 (3):287-96.

Gupta, S., S. Grant, and T. C. Melewar. 2008. The expanding role of intangible assets of a brand. Management Decision 46 (6):948-60.

Jack, E. P., T. L. Powers, and L. Skinner. 2009. Reverse logistics capabilities: Antecedents and cost savings. International Journal of Physical Distribution and Logistics Management 40 (3):228-46.

Jayaraman, V., and Y. Luo. 2007. Creating competitive advantages through new value creation: A reverse logistics perspective. The Academy of Management Perspectives 21 (2):5673.

Keller, K. L. 1993. Conceptualising, measuring and managing customer-based brand equity. Journal of Marketing 57 (1):1-1-22.

Kharas, H. 2010. The emerging middle class in developing countries: OECD development center, working paper no. 285. Accessed July 02, 2012, from weblink http://www.oecd.org/dataoecd/12/52/44457738.pdf.

Krikke, H., J. Bloemhof-Ruwaard, and L. N. Van. 2003. Concurrent product and closed loop supply chain design with an application to refrigerators. International Journal of Production Research 41 (16):3689-719.

Lapierre, J. 2000. Customer-perceived value in industrial contexts. Journal of Business and Industrial Marketing 15 (2/3):122-45.

Lee, C. K. M., and J. S. L. Lam. 2012. Managing reverse logistics to enhance innovation in sustainability initiatives of industrial marketing. Industrial Marketing Management 41 (4):589-98.

Lee, P.T.W, and J.S.L. Lam (2013) Fifth generation ports? competitiveness analysis on major asian ports, Proceedings of the International Workshop on Port Economics, Singapore, 9-10 December 2013.

Li, S., S. S. Rao, T. S. Raghu-Nathan, and B. Raghu-Nathan. 2005. Development and validation of a measurement instrument for studying supply chain management practices. Journal of Operations Management 23 (6):618-41.

Marquardt, A. J., S. L. Golicic, and D. F. Davis. 2011. B2B services branding in the logistics services industry. Journal of Services Marketing 25 (1):47-57.

O'Rourke, D. 2005. Market movements: Nongovernmental organisation strategies to influence global production and consumption. Journal of Industrial Ecology 9 (1-2):115-28.

OECD (2001), Information and consumer decision-making for sustainable consumption, OECD, Paris.

OECD Report. 2010. Business-to-business electronic commerce in publishing, retail distribution and pharmaceutical distribution in France. Unclassified Literature.

Pagell, M., and Z. Wu. 2009. Building a more complete theory of sustainable supply chain management using case studies of 10 exemplars. Journal of Supply Chain Management 45 (2):37-56.

Papavassiliou, N., D. Sharma, E. Archontoulis, and A. Liu. 2006. Total system integration in distribution channels. Journal of Marketing Channels 13 (2):29-49.

Payne, A., S. Holt, and P. Frow. 2001. Relationship value management: Exploring the integration of employee, customer and shareholder value and enterprise performance models. Journal of Marketing Management 17 (7-8):785-817.

Persson, G., and H. Virum. 2001. Growth strategies for logistics service providers: A case study. The International Journal of Logistics Management 12 (1):53-64. 
Power, D., M. Sharafali, and V. Bhakoo. 2007. Adding value through outsourcing. Contribution of 3PL services to customer performance. Management Research News 30 (3):228-35.

Prahlad, C. K., and A. Hammond. 2002. Serving the world's poor, profitably. Harvard Business Review 80 (9):48-59.

Richey, R. G., Jr., M. Tokman, R. E. Wright, and M. G. Harvey. 2005. Monitoring reverse logistics programs: A roadmap to sustainable development in emerging markets. Multinational Business Review 13 (3):41-1-65.

Seuring, S., J. Sarkis, M. Muller, and P. Rao. 2008. Innovation in sustainability initiatives and supply chain management - An introduction to the special issue. Journal of Cleaner Production 16 (15):1545-51.

Shocker, A. D., R. K. Srivastava, and R. W. Ruekert. 1994. Challenges and opportunities facing brand management: An introduction to the special issue. Journal of Marketing Research $31(2): 149$.

Simpson, P. M., J. A. Siguaw, and T. L. Baker. 2001. A model of value creation. Industrial Marketing Management 30 (2):119-34.

Srivastava, R. K., L. Fahey, and H. K. Christensen. 2001. The resource based view and marketing: The role of market-based assets in gaining competitive advantage. Journal of Management 27 (6):777-802.

Srivastava, R. K., T. A. Shervani, and L. Fahey. 1998. Market-based assets and shareholder value: A framework for analysis. Journal of Marketing 62 (1):2-18.

Stark, J. 2015. Product lifecycle management: Volume 1: 21st century paradigm for product realisation. Geneva, Switzerland: Springer.

Tibben-Lembke, R. S., and D. S. Rogers. 2002. Difference between forward and reverse logistics in a retail environment. Supply Chain Management: An International Journal 7 (5):271-82.

Van der Veen, G., and R. van Ossenbruggen. 2015. Mapping out the customer's journey: Customer search strategy as a basis for channel management. Journal of Marketing Channels $22(3): 202-13$.

Velor, C. 2007. The influence of information about labour abuses on consumer choices of clothes: A grounded theory approach. Journal of Marketing Management 23 (7-8):675-95.

Viswanathan, M., A. Seth, R. Gau, and A. Chaturvedi. 2009. Ingraining product-relevant social good into business processes in subsistence marketplaces: The sustainable market orientation. Journal of Macromarketing 29 (4):406-25.

VonRiesen, R. D., and N. C. Herndon. 2011. Consumer involvement with the product and the nature of brand loyalty. Journal of Marketing Channels 18 (4):327-52.

Vurro, C., A. Russo, and F. Perrini. 2009. Shaping sustainable value chains: Network determinants of supply chain governance models. Journal of Business Ethics 90 (4):607-21.

Webster, F. E. 2000. Understanding the relationships among brands, consumers and resellers. Journal of the Academy of Marketing Science 28 (1):17-23.

Weerawardena, J., and G. S. Mort. 2006. Investigating social entrepreneurship: A multidimensional model. Journal of World Business 41 (1):21-35.

Wernerfelt, B. 1995. The resource-based view of the firm: Ten years after. Strategic Management Journal 16 (3):171-74.

Wong, A., and A. Dean. 2009. Enhancing value for Chinese shoppers: The contribution of store and customer characteristics. Journal of Retailing and Consumer Services 16 (2):123-34.

Woodruff, R. B. 1997. Customer value: The next source for competitive advantage. Journal of the Academy of Marketing Science 25 (2):139-53.

$\mathrm{Wu}, \mathrm{H}$. J., and S. Dunn. 1995. Environmentally responsible logistics systems. International Journal of Physical Distribution and Logistics Management 2:20-38. 
$\mathrm{Zu}, \mathrm{X}$., and H. Kaynak. 2012. An agency theory perspective on supply chain quality management. International Journal of Operations \& Production Management 32 (4):423-46. 